\title{
MODEL PEMBELAJARAN PASSING SEPAK BOLA DI SD
}

\author{
Gutomo Harianto ${ }^{1}$, Mochamad Nurhadi ${ }^{2}$, Nur Wakit $^{3}$, Eko Sujarwo $^{4}$ \\ ${ }^{1}$ SDN Karangrejo I Kec. Ngasem Kab. Kediri, \\ ${ }^{2}$ SDN Karangrejo II Kec. Ngasem Kab. Kediri, \\ ${ }^{3}$ SDN Plosorejo I Kec. Gampengrejo Kab. Kediri, \\ ${ }^{4}$ SDN Tiru Lor 1 Kec. Gurah Kab. Kediri \\ Email: ${ }^{1}$ gutomo.harianto@yahoo.com, ${ }^{2}$ mochamadnurhadi2@gmail.com, \\ 33akit_64@yahoo.co.id, ${ }^{4}$ ekosujarwo52@gmail.com
}

\begin{abstract}
Abstrak: Latihan passing dalam sebuah latihan bertujuan untuk lebih mengasah kemampuan pemain dalam alur permainan. Hal ini juga akan melatih suatu kebiasaan untuk selalu mengutamakan suatu permainan tim dari pada kemampuan individu untuk mencapai kemenangan. Pada awal setiap latihan, alangkah baiknya bila diberikan kesempatan untuk berlatih menendang pada setiap pemain selama beberapa menit pada saat pemain mengadakan pemanasan. Dalam permainan sepakbola kerjasama antar pemain harus dikembangkan, sehingga suatu gerakan pola permainan tertentu mereka lakukan secara otomatis, kondisi fisik, kecepatan, sertateknik dasar merupakan faktor yang sangat penting. Untuk dapat menguasai dan lebih sukses dengan permainan sepakbola, pemain perlu didukung oleh kemampuan fisik yang prima. Berdasarkan pengalaman dan pengamatan sepakbola masa kini, komponen-komponen yang dibutuhkan dalam permainan sepakbola sangat menunjang kemajuannya.
\end{abstract}

Kata Kunci: Model Pembelajaran, Passing Sepak bola, SD.

Perkembangan olahraga di Indonesia dari tahun ke tahun semakin mengalami peningkatan. Hal ini dapat dilihat antara lain semakin banyak masyarakat melakukan olahraga sebagai bentuk gaya hidup. Salah satu olahraga permainan yang paling digemari dan dimainkan oleh masyarakat adalah sepakbola. Dengan demikian dapat dilihat bahwa permainan sepakbola semakin populer di Indonesia. Permainan sepakbola tidak hanya dimainkan dalam masyarakat saja tetapi di lingkungan sekolah, perguruan tinggi maupun instansi.

Untuk pembinaan yang mengarah ke pengembangan prestasi diarahkan kepada siswa yang berminat pada satu atau beberapa cabang olahraga yaitu sepakbola dapat dilakukan dalam kegiatan ekstrakurikuler. Pada kegiatan ekstrakurikuler yang diadakan diluar jam pelajaran, siswa bebas mengembangkan bakat yang telah dimiliki, siswa dapat bermain dalam satu cabang olahraga tertentu tanpa dibatasi oleh waktu pelajaran lain (Depdiknas, 2005: 9).

Kegiatan pengembangan diri atau ekstrakulikuler yang ada di sekolah pada umumnya olahraga permainan, salah satunya adalah permainan sepakbola. Seperti yang penulis adakan di SDN Karangrejo I Kecamatan Ngasem Kabupaten Kediri. Siswa banyak menyukai terutama siswa putra. Untuk bisa memainkan sepak bola dengan baik dan benar dibutuhkan penguasaan teknik yang baik. Teknik-teknik dasar yang baik itu meliputi: menggiring bola (dribbling), 
mengumpan bola (passing), menembak bola (shooting), menyundul bola (heading), dan menerima bola (receiving).

Namun demikian, tidak semua siswa dapat memainkan permainan sepakbola dengan baik, hal itu disebabkan karena dasar-dasar keterampilan bermain sepakbola belum sempurna. Diantara penguasaan teknik yang paling sulit dikuasai oleh siswa SDN Karangrejo I Kecamatan Ngasem Kabupaten Kediri adalah teknik passing. Pada dasarnya mengumpan bola (passing) merupakan teknik dasar yang paling sering digunakan dalam permainan sepak bola. Mengumpan merupakan keterampilan paling penting untuk menguasi sepak bola. Tetapi seringkali siswa melakukan beberapa kesalahan ketika passing seperti: (1) Laju bola tidak sesuai dengan jarak passing (terlalu keras atau terlalu lembek). Jika terlalu keras, bola tak terjangkau teman. Jika terlalu lembek, bola terpotong lawan, (2) Umpan tidak akurat (3) Mengumpan padahal waktunya menembak.

Untuk mengatasi kendala-kendala yang berhubungan dengan penguasaan gerak dasar passing, maka diperlukan model-model latihan yang sesuai dengan karakteristik dan kemampuan mereka. meliputi sikap persiapan, sikap perkenaan dengan bola, dan sikap akhir.

\section{PEMBAHASAN}

\section{Model Pembelajaran Passing Sepak Bola di SD}

Sepakbola adalah suatu permainan beregu yang dimainkan masingmasing regunya terdiri dari sebelas orang pemain termasuk seorang penjaga gawang. Sepakbola adalah permainan yang sangat populer, karena permainan sepakbola sering dilakukan oleh anak-anak, orang dewasa maupun orang tua.

Permainan sepakbola yang telah menawan banyak orang selama berabadabad, masih tetap memperoleh popularitas di seluruh dunia. Menariknya sepakbola mempunyai banyak sumber yang berbeda-beda, yang menyebabkan sepakbola begitu mempesona bagi pemain dan penonton. Penyebaran olahraga ini dimulai setelah perang dunia kedua. Maka semenjak itu sepakbola menjadi suatu permainan yang Nampak memasyarakat. Pahlawan-pahlawan pesepkbola bagaikan bintang-bintang yang bercahaya (yang menonjol) di tengah masyarakat, bahkan mereka adalah orang-orang yang paling terkenal di muka publik dan paling banyak penghasilannya.

Pengaruh yang hebat ini bertambah dengan dibantu oleh publikasi, seperti: koran-koran, majalah-majalah, penayangan langsung di televise dan penyebaran hal-hal yang terkait dengan klub-klub sepak bola dengan para pahlawanya dengan berbagai macam cerita dan kabarnya. Itu semua merupakan sarana yang digunakan untuk menarik simpati manusia terhadap olahraga dan para pemainnya.

Sepakbola ialah olahraga beregu, yang dilandasi atas teknik, pengolahan bola dan pengertian setiap pemain terhadap permainan. Faktor-faktor itu semua mempunyai peranan yang sangat penting.

Prinsip dalam sepakbola sederhana sekali yaitu membuat gol dan mencegah jangan sampai lawan berbuat yang sama terhadap gawang sendiri, yang memasukkan gol terbanyak memenangkan pertandingan. Kalau prinsip ini kita telurusi lebih jauh, maka kita dapat mengatakan sebagai berikut: (1) Untuk dapat 
gol kita harus menguasai bola. (2) Untuk mencegah gol oleh lawan, kita harus berusaha mengubah keadaan sehingga dari penjaga bola, kita menjadi pengusaha bola.

Dalam permainan sepakbola kerjasama antar pemain harus dikembangkan, sehingga suatu gerakan pola permainan tertentu mereka lakukan secara otomatis, kondisi fisik, kecepatan, sertateknik dasar merupakan faktor yang sangat penting. Untuk dapat menguasai dan lebih sukses dengan permainan sepakbola, pemain perlu didukung oleh kemampuan fisik yang prima. Berdasarkan pengalaman dan pengamatan sepakbola masa kini, komponenkomponen yang dibutuhkan dalam permainan sepakbola sangat menunjang kemajuannya.

\section{Langkah-langkah Model Latihan Pasing Sepak Bola Sikap Persiapan}

Sikap persiapan dalam melakukan passing adalah berdiri menghadap arah gerakan bola, kedua lengan agak terentang. Kaki bertumpu di samping bola dan pandangan terpusat pada bola. Tariklah kaki kanan ke belakang dan ayunkan ke depan untuk passing dengan menekuk pergelangan kaki ke bawah.

\section{Sikap Perkenaan Dengan Bola}

Usahakan saat passing, kaki di belakang bola. Perkenaan kaki pada bola tepat di tengah bola, berat badan ke depan. Tarik kaki yang digunakan passing ke belakang lalu ayun ke depan, kenakan bola bagian tengah.

\section{Sikap akhir}

Setelah melakukan passing, pindahkan berat badan ke depan. Lanjutkan gerakan searah dengan bola, gerakan akhir berlangsung dengan baik (Follow through).

\section{Tujuan}

Menghasilkam model latihan passing sepakbola bagi siswa putra setingkat Sekolah Dasar. Terampil dalam variasi latihan passing sepak bola. Bahwa variasi latihan yang penulis terapkan, sesuai dan dibutuhkan bagi siswa seusia tingkat SD yang mengikuti kegiatan ekstrakulikuler yang mempunyai tujuan: (1) Variasi Latihan 1, latihan passing dengan menggunakan kaki bagian dalam, (2) Latihan ini bertujuan untuk menguatkan otot-otot yang diperlukan untuk passing, (3)Variasi Latihan latihan passing dengan kaki bagian luar, (4) Latihan ini bertujuan untuk memperbaiki teknik-teknik passing, (5) Variasi Latihan 3, latihan passing dengan punggung kaki, (6) Latihan ini bertujuan untuk menguatkan otot pergelangan kaki, (7) Variasi Latihan 4, latihan passing berpasangan Latihan ini bertujuan untuk melatih kerjasama antar pemain, (8) Variasi Latihan 5, latihan passing ke dinding (wall bound), (9) Latihan ini bertujuan untuk memperbaiki teknik passing, (10) Variasi Latihan 6, latihan passing dan mengontrol Latihan ini bertujuan untuk memberikan umpan dengan tepat, (11) Variasi Latihan 7, latihan passing dan berlari Latihan ini bertujuan untuk koordinasi passing dan lari, (12) Variasi Latihan 8, latihan passing zig zag. 
Latihan ini bertujuan untuk memberikan bentuk latihan passing variatif, (9) Variasi Latihan 9, latihan passing jarak jauh. Latihan ini bertujuan untuk mendapatkan kekuatan dan akurasi passing, (10) Variasi Latihan 10, latihan passing jarak jauh dan menahan bola. Latihan ini bertujuan untuk melakukan passing bola jarak jauh serta dapat mengambil keputusan dengan cepat dan tepat.

\section{Manfaat}

Tentang model latihan passing sepakbola ini akan bermanfaat bagi guru pendidikan jasmani, terutama sekolah setingkat SD yang mengadakan kegiatan ekstrakulikuler mempunyai pedoman untuk melatih passing sepak bola pada siswanya. Bagi siswa yang memperlajari latihan passing, sehingga cepat meningkat kemampuannya dalam melakukan passing sepakbola. Menambah model dan variasi passing sepak bola

\section{Kelebihan dan Kekurangan}

Model latihan passing sepakbola di SD. Kelebihan, untuk menguatkan otot kaki, menambah kelincahan, keseimbangan serta menambah kreatifitas model passing. Kekurangan, rata rata siswa sekolah dasar masih lemah kekuatan otot kakinya, serta masih lugu tentang kelincahannya, masih kurang mengatur keseimbangan tubuhnya, dan pasih pakem dengan passing yang sederhana.

\section{KESIMPULAN}

Mengumpan bola (passing) merupakan teknik dasar yang paling sering digunakan dalam permainan sepak bola. Mengumpan merupakan keterampilan paling penting untuk menguasai sepak bola. Menendang bola mempunyai tujuan untuk memberikan atau mengoper bola kepada kawan (passing). Passing yang baik dimulai ketika tim sedang menguasai bola menciptakan ruang diantara lawan dengan bergerak dan membuka ruang di sekeliling pemain. Passing yang efektif memberikan peluang yang lebih baik untuk mencetak gol.

\section{SARAN}

Dengan latihan passing permainan sepakbola akan mempermudah akan memberikan solusi pemecahan masalah pada kegiatan ekstrakurikuler sepakbola di SDN Karangrejo I Kecamatan Ngasem Kabupaten Kediri yaitu minimnya variasi model latihan passing sepakbola yang menyebabkan siswa menjadi kurang tertarik saat melakukan latihan passing. Kegiatan ekstrakulikuler sepakbola dengan peran guru diharapkan bisa terinspirasi untuk menciptakan model latihan passing sepakbola yang lain, sehingga dalam setiap latihan, siswa akan mempunyai banyak variasi model latihan passing dan tidak jenuh atau malas untuk melakukan latihan passing. 


\section{DAFTAR RUJUKAN}

Departemen Pendidikan Nasional. 2007. Pengembangan Model Pembelajaran Permainan Sepakbola Mini: Kombinasi teknik Dasar. PPPPTK Pendidikan Jasmani dan Bimbingan Konseling: Jakarta.

Endang, Widyastuti. Agus Suci. 2010. Pendidikan Jasmani, Olahrga, dan Kesehatan untuk SD/MI Kelas VI. Pusat Pembukuan Kementerian Pendidikan Nasional: Jakarta.

Hariyono.1991. Sepakbola I. Malang. IKIP Malang. 